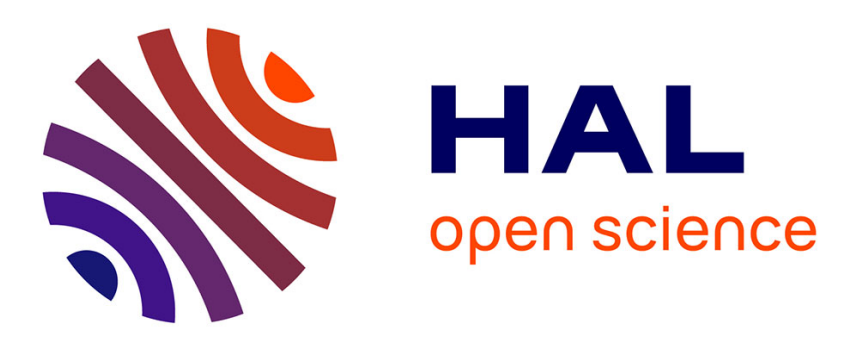

\title{
Uncertain tourism: Evolution of a French winter sports resort and network dynamics
}

\author{
Yohann Rech, Elodie Paget, Frederic Dimanche
}

\section{To cite this version:}

Yohann Rech, Elodie Paget, Frederic Dimanche. Uncertain tourism: Evolution of a French winter sports resort and network dynamics. Journal of Destination Marketing \& Management, 2019, 12, pp.95 - 104. 10.1016/j.jdmm.2019.03.003 . hal-03480659

\section{HAL Id: hal-03480659 \\ https://hal.science/hal-03480659}

Submitted on 20 Dec 2021

HAL is a multi-disciplinary open access archive for the deposit and dissemination of scientific research documents, whether they are published or not. The documents may come from teaching and research institutions in France or abroad, or from public or private research centers.
L'archive ouverte pluridisciplinaire HAL, est destinée au dépôt et à la diffusion de documents scientifiques de niveau recherche, publiés ou non, émanant des établissements d'enseignement et de recherche français ou étrangers, des laboratoires publics ou privés.

\section{다)(1) $(5$}

Distributed under a Creative Commons Attribution - NonCommercial| 4.0 International 


\section{Uncertain tourism:}

\section{Evolution of a French winter sports resort and network dynamics}

Yohann Rech ${ }^{\mathrm{a}}$, Elodie Paget ${ }^{\mathrm{b}}$, Frederic Dimanche $^{\mathrm{c}}$

${ }^{a}$ Univ Rennes, VIPS ${ }^{2}$ - EA 4636, F-35000 Rennes, France

E-mail address: yohann.rech@univ-rennes2.fr

${ }^{\mathrm{b}}$ Univ Rennes, VIPS ${ }^{2}$ - EA 4636, F-35000 Rennes, France

E-mail address: elodie.paget@univ-rennes2.fr

${ }^{\mathrm{c}}$ Ted Rogers School of Hospitality and Tourism Management, Ryerson University, 350

Victoria Street, Toronto, Ontario, M5B 2K3, Canada

E-mail address: fdimanche@ryerson.ca

\section{Corresponding author: Yohann Rech}

Univ Rennes, VIPS ${ }^{2}$ - EA 4636, F-35000 Rennes, France

Postal address: Campus La Harpe, Avenue Charles Tillon, CS 24 414, 35044 Rennes Cedex, France

E-mail address: yohann.rech@univ-rennes2.fr 


\section{Evolution of a French winter sports resort and network dynamics}

3

4

\section{Introduction}

France has an important position in the international winter tourism market. With 51 million skier visits during the winter of 2016-2017 (Vanat, 2018), it ranks second in the world just behind the USA and ahead of Austria. France has 336 winter sports resorts with a total of 3391 lifts (1121 aerial lifts, 2238 ski lifts and 32 other lifts), which represent $18 \%$ of the worldwide capacity (STRMTG, 2015). Seven mountain ranges are suitable for skiing, and among them, the Alps (Northern and Southern) have the largest number of lifts. In fact, these two ranges alone account for 204 winter sports resorts. While there were ski resorts before the 1960s, the era of planned development of the mountains began in France in 1964, when a proactive state policy led to the rapid growth of the tourism sector. As Guerin (1984, page number required) explains, "the setting up on August 10, 1964 of an Interdepartmental Mountain Planning Committee to coordinate and guide investments for the creation of winter sports resorts is a fundamental date because it is the realization of an idea: the mountain is a playground." Many resorts were created thanks to this deliberate tourism policy and the national 'Snow Plan' in 1970 accentuated this development. From the 1980s, the creation of new resorts became a rare event and there were instead expansions or connections between existing resorts. In contrast, the lift capacity for transporting skiers was greatly increased and most facilities have been renewed in the past few years.

Mountain tourism represents a very important market in France, with $€ 9$ billion of revenues (ATOUT France, 2015). However, the strong development of the sector up until the beginning of the 2000s has tended to slow and serious difficulties have emerged. Winter tourism (and particularly the skiing market), which was for a long time considered as 'white gold,' has experienced important changes. The difficulties are both conjectural and structural. There are especially large differences among the regions and among the mountain ranges (for example even in the heart of the French Alps, the Northern Alps offer larger and more famous resorts such as Chamonix, Megève, and Les Arcs), but there are also disparities with regard to resort management. In France, the ski resorts can be managed by public bodies, by private operators, or be the result of a public/private partnership. Moreover, an ever-greater dichotomy can be observed between the large and very prosperous resorts, which have a vast 
ski area at over $2000 \mathrm{~m}$ altitude (with glacier skiing) and others, much smaller, located at lower altitudes with a diminishing clientele. If winter sports resorts are particularly vulnerable to climate change (Agrawala, 2007; Simpson, Gössling, Scott, Hall, \& Gladin, 2008), this is even more dramatic for those that are located at lower altitudes. As explained by Soboll and Dingeldey (2012, p.102), "several ski areas, particularly the smaller ones at lower altitudes, might cease ski operations and switch to snow-independent forms of winter tourism or to summer tourism instead." Faced with the current climate evolution and haphazard snowfalls, these ski resorts experience increasing difficulty to provide services for the whole of the winter season. As highlighted by Scott, McBoyle, Minogue, and Mills (2006, p.393), "climate change will create winners and losers in the ski industry of eastern North America." This statement is equally valid for Europe as shown by studies in Sweden (Moen \& Fredman, 2007), Austria (Wolfsegger, Gössling, \& Scott, 2008), or Switzerland (Elsasser \& Messerli, 2001). The risks are not concentrated in only one geographical region: they are felt just as much in North America as in Australia (Morrison \& Pickering, 2012) or in the Alps (Elsasser \& Urki, 2002; Koenig \& Abegg, 1997).

This research project aims to understand how resorts are facing change. The study focuses on all the conjectural (e.g. climatic risks, economic development, etc.) and structural (e.g. changes in the management of the resorts, development of the services provided, etc) changes that produce new forms of organization within the resorts themselves. These can be analyzed according to Callon et al.'s (2011) study, which explains that there is a significant difference between risk and uncertainty. In the first case, scientific knowledge is sufficiently advanced to make well-grounded decisions, while in the second, situations are more complex because knowledge is not yet well-established. Changes affecting winter sports resorts relate more to the second case because on the one hand, there is a controversy (or several) with regard to these changes (e.g. about climate change), while on the other hand, winter tourism mainly suffers from uncertainty (about the clientele, the economic situation, the snowfall, etc). Climatic uncertainty particularly illustrates this situation. Some winter seasons can present numerous episodes of snowfall whereas others can be dry and thus catastrophic from a winter tourism perspective. The situation is even more complicated because a very snowy season can also turn out to be disastrous: the weather can be so bad that it deters holidaymakers from choosing a winter vacation. It is therefore uncertainty that is dominant, since no model can predict long-term development. For this reason, the definition of an appropriate tourist policy remains complex and reflects the need to 'act in an uncertain world' (Callon et al., 2011). The analysis of the changes proposed by this study therefore allows a 
shared exploration 'of possible worlds' by discussing the suitability of certain political choices. It is above all a question of understanding how actors are involved in these tourist controversies and what the terms of the debate are. It is also a matter of comprehending how these controversies help to create the 'collectives', integrating actors into the debate and mobilizing spokespeople from sports, tourist, environmental, or user associations. From this perspective, actor-network theory (Callon, 1986; Latour, 2005; Law, 1994) is particularly relevant as it captures new forms of organization and 'collectives' that are created due to the new developments that affect resorts.

\section{Actor-network theory and tourist uncertainties}

\subsection{Actor-network theory as a background}

This study adopts a social constructivist approach with actor-network theory (ANT) serving as the foundation to understand how the actors adapt to the changes that take place in ski resorts and how they manage nature. The aim of ANT is to show how technical or scientific innovations are made possible because of the association of human and non-human entities, which together can form a socio-technical network (Akrich, Callon, \& Latour, 2002; Latour, 1987, 1996). This sociological approach deals with the society being formed and tries to understand how 'collectives,' uniting various entities, are produced. It thus rejects the sociologizing conceptions that explain social facts by other invisible social dimensions. Collective action is composed of individuals but also of objects that classical sociology leaves aside. The socio-technical networks being formed, which bring the innovations (or which are at the core of important controversies), have therefore this particular quality: they are hybrids that are composed of humans and non-human entities. One of the specificities of the actornetwork theory is thus to transcend the classical dichotomies upheld by the social sciences, not only between the technical and the social, but equally between the individual and the group, the micro-logical and the macro-logical, and even more between the social and nature.

The epistemological position of this approach rests on four principles (Law, 1994). The first is the 'principle of symmetry' (Callon, 1986). This does not mean egalitarianism between humans and non-humans, but simply that the researcher should not "impose a priori some spurious 'asymmetry' among human intentional action and a material world of causal relations" (Latour, 2005, p.76). While the modern world has created a great division between 
103 humans and non-humans, it is, in contrast, a matter of reconsidering all entities that transform

104 the action. In fact, non-human entities have a capacity to perform the social, that is, to transform it and recompose the relations among the actors. The second principle is that of 'reflexivity'. It is fundamental in ANT as it is a strongly epistemological position. Law (1994) refuses to think that sociologists are observing the actors they are studying from afar. In fact, even if the concepts used are different and the professional aspirations are divergent in terms of purpose, all are participating together in the same movement. However, it is not a question of objectivizing the actors' words but rather of following them in their explanations and their activities (Latour, 1993). The actors are credited with the ability to explain their actions and to have true self-reflexive activity on their actions. The position that sociologists hold in their field of study is therefore redefined. It is a question of rethinking authority and no longer establishing an asymmetry between the experts (the scientists) and the uninitiated (the actors). The third principle is that of 'non-reductionism'. This concludes that the social cannot be reduced to a priori categories. The approach is therefore close to ethnomethodology (Garfinkel, 1967) and this precept of 'non-reductionism' can only be applied if one begins to describe before explaining, by telling 'in-depth stories' (Law, 1994). Finally, the fourth principle is that of 'recursiveness'. This is a matter of considering the social in its dynamics and its instability. The social realm moves and is in perpetual transformation. Society is not stable but uncertain and it is precisely this dimension that seems to be the most relevant to understand contemporary mutations.

While actor-network theory has unquestionably contributed heuristically to sociology and therefore to the understanding of social reality, it has also been the subject of much criticism and is relatively divisive in the field of social sciences. Like any theoretical approach, it presents limits that must be acknowledged. Several critiques have addressed ANT, particularly in the field of science studies (Bloor, 1999). Such critiques particularly concern the limits of symmetrical anthropology (Chateauraynaud, 1991; Grossetti, 2007) and the metaphorical dimension of networks (Dubois, 2007). The controversies surrounding ANT are numerous and need to be integrated to avoid any dogmatic use of this approach.

\subsection{ANT and tourism}

Actor-network theory has already formed the basis for various tourism studies (e.g., Dedeke, 2017; Franklin, 2004; Johannesson, 2005; Jørgensen, 2017; Paget, Dimanche, \& Mounet, 2010; Ren, Pritchard, \& Morgan, 2009; Ren, 2011; Rodger, Moore, \& Newsome, 
2009; Tribe, 2010; Van der Duim, 2007). It can be considered a new field of research in tourism (Cohen \& Cohen, 2012). However, in spite of this trend for research on tourism from the ANT perspective, there is a certain fragmentation in the field of these studies. They are, in fact, very diverse in terms of the objects of study and they vary from empirical to theoretical (or even epistemological) considerations, and from case studies to more general analyses. The main interest of ANT is to be able to comprehend tourism in its dynamic state, while at the same time investigating it at multiple levels, going beyond the classical borderline between local and global. It is also a way of understanding the phenomenon of generalized mobility which tourism represents. According to Urry (2005, p.189), "this mobility is produced by hybrids, flowing along 'scapes.' These networks include 'physical' and 'human' entities, whose power derives from their complex and fluid association." Therefore, ANT allows for the understanding of the tourist phenomenon that is in fact a hybrid network of actors and things. Objects fully participate in the creation of the tourism site and this materiality performs the tourism site as much as the tourists themselves (Johannesson, 2005; Ren, 2011). For Van der Duim (2005, p.86), "a concern with materiality in tourism is a concern with cars and planes; restaurants, campsites and hotels and their supplies; and natural objects like seas, beaches, hills and lakes and their related flora and fauna." ANT also allows the researcher to produce a territorial diagnosis of tourist destinations, by including how translation processes (Callon, 1986) are accomplished. It is, for example, what Arnaboldi and Spiller (2011) propose in the study of cultural districts, explaining that the collaboration among actors is possible when three stages are in place: enrolling actors, fact-building, and circulating translations. In the same vein, Paget et al. (2010) have shown how a ski resort can be considered to be a hybrid network and how a tourism innovation can be imposed when a translator (in this case an entrepreneur) commits himself to making it work and manages to mobilize a collective around his project.

\subsection{Winter sports resorts as an uncertain world}

The conceptual framework of this research is based on ANT. However, it is difficult to consider this theoretical approach in its entirety, without bearing in mind the changes it has experienced over the past 30 years. The weakness of the tourism studies that have mobilized ANT is perhaps to have been mainly inspired by the sociology of translation, without taking into account recent theoretical developments (Rech \& Paget, 2017). By starting from a common foundation of the ANT concepts, the specificity of the present research is to mobilize 
171 the traditional approaches to ANT (Callon, 1986; Latour, 1987) while also provoking 172 reflection using more recent theories which constitute developments in this approach. Indeed, 173 the latter, addressed in Politics of nature by Latour (2004) as well as in Acting in an uncertain 174 world by Callon, Lascoumes, and Barthe (2011), offer a particularly relevant framework for 175 studying tourism sites. They help to better understand the dynamics of change that can occur 176 and the strategies of resistance faced to certain developments, as well as the hybrid forms that 177 emerge and generate controversies restructuring the social. This perspective, in fact, allows 178 controversies to be researched that are of importance in the tourism sector and have, to date, 179 been the subject of little research.

180 In order to analyze the current developments in winter sports resorts, this research 181 project was based on three propositions from Latour (2004). The first is to discover how many 182 humans and non-humans make up the socio-technical network, called the 'collective'. Thus, it 183 is necessary to find the number of entities that participate in the collective action. Latour 184 (2004) calls this the power to take into account. It aims to identify entities that can integrate 185 debates but also clarify the terms of the debate. The second proposition is to know whether humans and non-humans can live together in a collective. Latour calls this the power to put in order. It is a question of understanding, on the one hand, how the common problems are ranked and, on the other hand, how they are institutionalized and formalized. Lastly, the third proposition concerns the exploration of common worlds: the way in which a new governing system is installed. Following this, Callon et al. (2011) have shown how technological and scientific developments do not always create certainty with regard to future situations. Public policies are made in emergency situations where all the information cannot be crossreferenced and above all, they are often written without established scientific knowledge. According to this, we can state that lower altitude ski resorts, faced with the serious consequences of change (e.g. climate evolution, customer volatility, international competition, quick transformations in sports practice) are in situations of uncertainty that render management very complex. Tourism policies should adapt to unexpected situations and try to respond to different problems and questions: Will lower altitude ski resorts continue to receive snowfall in the long term? Should they invest in new lift equipment without a clear view of the future? Should public investments be chosen in spite of the financial difficulties of the local authorities or should they find private investors? How can they diversify resort supply without knowing precisely how demand will evolve? It is however not possible to have clear answers to those questions at the moment. 


\section{Methodology}

\subsection{Presentation of the field investigation}

The field investigation for this research took place in the Natural Regional Park of Chartreuse (see Figure 1) in the Northern French Alps. This is a case study (Miles \& Huberman, 1994) and is conducted at two levels. The first is very local as it is the study of a

212 former winter sports resort, the col du Coq. This resort stopped operating in 1995 but the ski 213 lifts are still in place, although unused. It was a 'micro ski resort' like many in France, composed of some ski lifts and located at about $1400 \mathrm{~m}$ altitude. The site is therefore marked by its tourism past and over the last few years has become a brownfield site. Despite the fact that the resort is no longer active, it is still very popular, especially for winter sports activities (snowshoeing, ski touring, sledding, etc). The site has no buildings to offer on-site accommodations to tourists. Tourist accommodations are therefore not at the resort but below it in the nearby villages. The second level of analysis is at a more territorial level and explores the links between this former winter sports resort and the neighboring resorts on the same mountain range. These winter sports resorts are also small in size but continue to function, even though they are located at a lower altitude $(900 \mathrm{~m})$ and are experiencing serious difficulties. These are the Saint-Hilaire, Saint-Bernard, and Saint-Pierre de Chartreuse resorts which belong to the territory of the Plateau des Petites Roches (PPR).

The field investigation site was chosen on the one hand because it corresponded to the researchers' desire to investigate a tourist controversy by studying a winter sports resort. The col du Coq resort matches this because it has been closed and has been the subject of local debates about the future of the site. Indeed, the $\operatorname{col} d u$ Coq site is very busy in winter and has

232 better snow conditions than other ski resorts at lower altitudes. As a result, the question of its 233 tourist future arose as well as that of its commercial exploitation. On the other hand, the 234 Natural Regional Park of Chartreuse funded the study. The choice of the field study was made 235 in agreement with the scientific director of the Park as well as the manager of outdoor 236 recreation, in order to respond to their concerns. Therefore, the analysis of the controversy can 237 be conceived as a decision-making aid, since the Natural Regional Park of Chartreuse had to 
make important political choices to define a future for this site, while at the same time defining a global strategy for the other ski resorts in the territory.

\subsection{Qualitative research}

The research project was carried out using a comprehensive (Weber, 1978) and inductive (Glaser et Strauss, 1968) approach. Taking a qualitative perspective (Hollinshead, 2006; Jamal \& Hollinshead, 2001; Pernecky \& Jamal, 2012; Phillimore \& Goodson, 2004; Riley \& Love, 2000; Walle, 1997; Westwood, Morgan, \& Pritchard, 2006), the empirical material collected rests on different methods of investigation, where data triangulation sought to guarantee the reliability of results and allow for an objective analysis (Decrop, 1999; Thietart, 2001; Yin, 2003). A multi-method approach was thus used, consisting of personal interviews (with two different target publics: the site actors and the users), documentary analysis, and observation.

The study sample was composed of 25 site actors. An interview guideline was prepared in advance according to several dimensions related to the problem and semi-structured interviews were conducted. Specifically, the actors (concerned by the site or by the former resort) were asked about:

- Their respective roles, their objectives, their strategies and their (conflictive or cooperative) relations with the other actors;

- The site and the different practice areas, the sports facilities and products;

- The involvement of the actor in the tourist controversy concerning the future of the resort and its representation of the management mode that should be chosen (e.g. tourism management, environmental management);

- The representation of changes and existing problems (e.g. climate, accommodation, high usage rates);

- Tourist and leisure policies, and choices concerning the future of the low altitude resorts. precepts of ANT, by following the actors and the controversy. The relevant actors who could 
elected representatives. First, the actors were chosen who directly or indirectly structured the context of the action, and this list of actors was later extended as the study progressed. The number of actors is limited by the small size of the tourist site. Most of the relevant actors were interviewed. As a result, the researchers met the protected area managers, the municipal and inter-municipal elected officials, the staff of tourist offices, a host, the sports service providers, the sports and leisure associations, an association of environmental protection and a farmer (see Table 1).

[Please insert table 1 about here]

To complement the interviews carried out with the site actors, a series of interviews was also conducted with the site users. Consideration of the demand is a factor to take into account because, as Frochot and Kreziak (2008) pointed out, non-ski snow activities have been the subject of significant development by resorts. The case of the col $d u \operatorname{Coq}$ resort is interesting because the ski lifts are unused, but the site is very popular and the practitioners come necessarily for activities other than alpine skiing. These interviews were thus important to understand the site users' points of view in the face of the plans for the resort and their position in the controversy. A total of 24 four interviews were conducted during the winter season with the people who used the $\operatorname{col} d u$ Coq area for recreational activities. These interviews were midway between semi-structured and comprehensive interviews (Mucchielli, 1996). They were carried out face-to-face on site, after subjects had finished their activities. In order to have different profiles for those practicing the activities, the survey area on the site was varied, as were the days on which the interviews took place (i.e. weekdays, weekends, holidays), the time (i.e. morning, midday, evening) and the weather conditions (i.e. good weather, cloudy weather, mist, and snow). A specific interview guide was created. The dimensions of this guide dealt with: (1) the use of the col du Coq site (in terms of activities, routes, frequency of attendance, and activity modalities), (2) the interviewee's perceptions of the site (knowledge of the site with regard to the area and the environment), (3) the development of the site and its 'tourist' future (notably the question of the re-launching of the winter sports resort), and (4) perceptions about site management. The interviewees could also address other topics in the discussion. These elements were to help understand their perception of the controversy and their level of involvement.

In addition, many documents were identified and analyzed, such as agreements between actors, leases, cadastral maps, tourist brochures, cartographic data, management 
plans, local municipal ordinances, and minutes of meetings. All these elements are the many traces of the social that enable to reconstruct the associations of actors (Latour, 2005) and to trace their links.

Finally, observations were carried out on site. They allowed for a detailed study of the different activity areas in order to ask the actors the most relevant and precise questions possible. Observations were also made of the people practicing sports in order to comprehend the different ways in which the site is used. Ethnographic surveys were carried out using a research blog, where all relevant information for analysis was recorded.

\subsection{Data analysis}

All interviews were recorded with the agreement of the interviewees. They were transcribed in their entirety and then analyzed using a content analysis grid (Bardin, 2007). This analysis grid was composed of the topics of the interview guide that was related to the central thesis, and that was completed with new dimensions that appeared in the interviews. Finally, these topics were also developed during the analysis itself because following a controversy (Latour, 2005) is useful to integrate elements of discourse and arguments that may be important and were not previously considered. Moreover, the data analysis requires the production of a somewhat random report (Latour, 2005). It means considering the researcher as an integral part of the research context (and not as an individual looking down on what he or she is studying). The study resulted in a research report that presented the issues around the controversy and that served as a decision-making tool for those who manage the site.

\section{Results: Description and analysis of a tourism controversy}

The analysis of socio-technical controversies is an excellent means of exploring the stakeholders, redefining the problems and describing the role of the protagonists (Callon et al., 2011). To follow the actors in the controversy is to understand how their relations and their organization are transformed. The changes that affect low-altitude resorts produce organizational transformations and the ANT allows us to better understand them. First, the origins of the tourist controversy and the role of the actors will be described, An in-depth analysis of the arguments that are developed will then be undertaken. Finally, the analysis will 
focus on three essential elements that contribute to redefining the relationships between actors: the snow as non-human and unpredictable, the changes in supply and accommodation needs, and finally the way to promote the site.

4.1. Tourism actors in the controversy

This first part of the results refers to the power to take into account (Latour, 2004) and thus to the census of the actors involved in the controversy to understand their degree of involvement. The first task of collecting the entities involved in the action is not carried out $a$ priori but is the result of the interviewing work by following the actors and the controversy. This is important as it allows a better understanding of how the controversy, through different stages, helps to redefine relations and the tourism network. The development of the col $d u$ Coq resort presents different aspects of a controversy, which can be qualified as 'touristic' in the sense that the site's future remains unresolved and that each actor deploys particular arguments concerning this uncertainty.

It is necessary first to explain the object of discord and to go back to the beginning of the controversy. While the organization of the different activities at the col $d u \operatorname{Coq}$ raises various problems, the question of the re-opening of the ski lifts is a central point. In fact, the col du Coq resort has been closed since 1995 and it has gradually become a brownfield site. However, after some years, the resort has begun to experience renewed interest from local stakeholders, despite the advent of climate change. The project to re-launch the resort has provoked an important debate at the local level. The discord is not just about re-launching the resort: it takes different forms that oppose in a complex way those in favor and those against the resort. There is a whole range of positions that can be observed and which can, at times, be seen changing. The controversy has taken a socio-technical dimension in the sense that it involves a variety of actors (managers, elected representatives, sport providers, hosts, environmentalists, etc) around the various physical elements: re-appropriation of a touristic area, development of the site, dismantlement or re-launching of the ski lifts, whether or not to clear snow from the roads, climate change and sustainability of resorts at lower altitudes, environmental uncertainty on the impact of outdoor activities, creation of car parks and the resulting consequences in terms of attendance.

Four types of actors are involved in the development of tourist activities at the col $d u$

371 Coq. First the elected officials who revolve around Saint-Pierre de Chartreuse, who are 372 responsible for the tourist area but do not want to develop alpine skiing facilities. Second, the 
ecologists, the technicians of protected areas, as well as some lower altitude mountain guides, who do not want the mountain to be developed and advocate the dismantlement of the abandoned pylons. Third, the tourism stakeholders on the territory of the PPR, who are mobilizing to re-launch the $\mathrm{col} d u$ Coq ski resort. Fourth, the elected officials of the PPR, who wish to develop their own small winter sports resort, and to give up on the col du Coq, against the advice of tourism stakeholders. All these actors are inter-related around the same common problem: how to use the $\mathrm{col} d u \mathrm{Coq}$ tourist area. However, the approach in terms of 'local order' (Friedberg, 1996) only provides a partial reading of the situation as in reality, this common 'spatialized' problem contains multiple problems referring to action contexts that are distributed all over the Chartreuse territory. The controversy has a very complex spatial dimension that should be addressed in terms of networks. The action context of the col $d u$ Coq can only be understood by tackling the situation of the other local winter sports resorts. ANT is therefore particularly relevant in this analysis because, as Latour (2005, p.200) explains, "what is acting at the same moment in any place is coming from many other places, many distant materials, and many faraway actors." Moreover, each group of actors brings a different answer to the general question, wanting to introduce entities into the collective that others do not want (ski lifts, development of commercial buildings, roads, etc).

\subsection{The arguments mobilized in controversy}

Before addressing the complexity of the controversy, it is important to summarize the different arguments that the various opponents have deployed to justify their positions in the controversy (see Figure 2).

First argument: Abandonment of the project to re-launch the ski resort. The elected officials from the territory of the PPR and from the heart of the Chartreuse range are almost unanimous, in spite of the tensions among them, in that the col $d u$ Coq resort should not be re-launched. For the elected officials of the middle of the Chartreuse Park, apart from economic reasons, environmental arguments are put forward against bringing the ski lifts back into service: "it doesn't interest us, not because that competes with us here, but simply because it is a unique site; it is a site which should be protected; it is a site which would cost an enormous amount of money and we know it" [elected public official from Saint-Pierre de Chartreuse]. The villages at the heart of the Chartreuse region have no particular ambition to develop alpine skiing on this site. Regarding the PPR, the justification used by the elected representatives mainly focuses on economic arguments and on the general interest that is to 
encourage the development of the PPR territory: "These were the conclusions of the work in the [Natural Regional] Park where we all worked together, we were all working on it, especially Saint-Bernard and Saint-Hilaire and as it was seen that our resorts were operating, we could see that we didn't have the means to have a third. In any case, it was the money that was the sinews of war" [elected representative of Saint-Hilaire]. The elected officials justify their preference for not investing in the col du Coq by also focusing on the difficult territorial network of the col du Coq: 'Saint-Pierre de Chartreuse didn't play the game; well that's true. On the other hand, I understood the mayor at that moment who already had a lot of difficulties with his resort and didn't want to weigh himself down because it was his responsibility, the col du Coq is Saint-Pierre de Chartreuse's responsibility; we shouldn't forget that either" [elected representative of Saint-Hilaire].

Second argument: Dismantlement of the resort. This argument suggests that the site of the resort is problematic because it is the interface among several protected areas. All the various managers of these areas share the desire to not re-launch winter tourism activities that would require significant development of facilities. Therefore, an environmental and reasoned management is more recommended. For these actors, a tourism site is incompatible with a protected area (which possesses significant regulatory prerogatives). As one of the managers said, "political choices had to be made" [environmental manager of departmental council], either by developing winter tourism, or by creating protected areas. Furthermore, the managers also put forward the idea that the development of the resort contradicts the spirit of the charter of the Natural Regional Park. Some outdoor recreational activity providers such as lower-altitude mountain guides are proponents of these types of arguments and some even advocate, similar to environmental militants, the dismantlement of the old ski lifts: "I think we need action from 'Mountain Wilderness' [an NGO] to dismantle all the pylons if things stay the same" [mountain guide]. Another outdoor recreation provider said almost the same thing: "I am for the dismantlement and the return of the col du Coq terrain to what it was like when I was a boy. It's no longer any good for anything" [mountain guide]. The arguments mobilized by users with regard to the future of the site and the problem of the 'detouristification' of the area are the same. Some talk about the place in terms of a tourism brownfield site and advocate the dismantlement of the pylons. The impact on the landscape of the old abandoned resort is highlighted. These are individuals who sometimes clearly perceive the impact of climate change on the lower-altitude resorts and are radically opposed to artificial snow. 
Third argument: Development of Nordic skiing. The development of this activity is often mentioned. A significant number of cross-country skiers leave from the col $d u$ Coq resort to ski to other Nordic skiing sites. Some cross-country skiing trails are only $100 \mathrm{~m}$ away from the old station of the col $d u$ Coq. Among the various developments under study to develop the col $d u C o q$, snowshoeing and Nordic skiing are considered as a means of development: "There is a forest road that will start, which could be used in winter for Nordic skiing and the snowshoe, which would allow an easier junction of the col $d u C o q$ and the col de Porte than at present" [elected representative from local council community]. The elected officials put forward the idea that there should be a common tax for the different resorts and above all the possibility of marketing a more extensive product. The development of the mountain through Nordic activities is thus perceived as a means of developing a soft and alternative tourism: less harmful and expensive than the development of a ski resort.

Fourth argument: Snow clearing from the road. Clearing snow from the road is another point of dissension. During the winter of 2008, the road to the col du Coq had been cleared less frequently than in previous winters (no scattering of salt, irregular clearance of snow, etc). This is very important as it impacts the number of visitors and the type of people who come to the site. The people who are opposed to snow clearing either have environmental motives (salt reduction) or are pleased with the fact that it 'naturally' regulates the number of visitors. Political decisions have been taken to lessen road clearance in winter: "As the col $d u C o q$ is closed, there is no activity anymore, at one time we asked to stop salting, after the houses" [elected representative from Saint-Pancrasse]. This type of decision has of course a limiting effect on the frequentation of this space. On the other hand, some actors wish the road to be cleared to allow the development of the site and the activities. "At the level of the activity it raises a problem in the sense that if there is a lot of snow, I can not take my clients up there [...], snow clearing is problematic for me at the level of my activity" [Hiking provider].

Fifth argument: Re-launch of the resort. Finally, another group of actors (hosts, etc.) declare that they are for the re-launch of tourist activities in the col $d u$ Coq. One of the main arguments is the complementary nature of the PPR resorts and above all the prospect of guaranteeing snow. Indeed, because the $\mathrm{col} d u \mathrm{Coq}$ resort faces north it is seen as a way to alleviate the snowfall problems. For them, the site has a higher degree of snowfall than the two resorts of the PPR. Thus, if it were re-launched it would allow tourism to be maintained: "20 or 30 years ago, we could say that there is no snow at Saint-Hilaire but that isn't a 
474

475

476

477

478

479

480

481

482

483

484

485

486

487

488

489

490

491

492

493

494

495

496

497

498

499

500

501

502

503

504

505

506

there was snow and a ski school, there were no problems and people came" [holiday cottage owner]. The arguments put forward also reflect individual interests as the tourist development of the col $d u C o q$ would be a way to ensure year-round economic activity whereas at the moment, it is very uncertain. Furthermore, the re-launching of the resort is mentioned by some sports people (mostly locals) who would like to have a rope-tow for children instead of the re-opening of the ski lifts.

[Please insert figure 2 about here]

\subsection{Snow, an unpredictable, non-human entity}

Snow is a non-human entity that produces uncertainty in winter sports tourism. In fact, scientists have stabilized their knowledge on global warming (Latour, 2015) and the elected representatives of the tourist municipalities have to make decisions regarding the development of the mountain for tourism purposes. Thus, an elected representative from the PPR commented on the new tourist policy in this French department (a territorial administrative unit): "The department does not want to reinvest in the resorts, it's over. The resorts at lower altitude with climate change, I don't know if they will last, if they are a tangible reality. But elected officials do not want to invest in the resorts" [elected representative from SaintPancrasse]. This is at the heart of the problem of acting in an uncertain world as described by Callon et al. (2011). The organizational uncertainty that results from random snowfalls at lower altitude does not come from the actors but from things. Without snow, snow-based tourism no longer exists. As one policy-maker explains: "We cannot attract so many people in winter if there is no snow. So in my opinion the problem is still pending. We can do lots of things; it's true we can diversify, people no longer come just for the snow, just to ski, [...] but with no snow they don't come at all" [elected representative from local council community]. The presence of snow makes winter tourism possible but does not eliminate uncertainty. On the one hand, the period when it snows has to coincide with the high season in the resorts (which in France corresponds to the Christmas holidays and the school holidays in February). On the other hand, the presence of snow is impossible for the actors of tourism to anticipate: “The people who call from all over France to ski, the first thing they say is: 'Is there snow?' I always tell them I rent you the facilities, the chalet, I order snow but I can't promise it. I can't put it in black on white" [holiday cottage owner]. This uncertainty is therefore particularly 
complex to manage for the tourism stakeholders because it is difficult to guarantee product 508 quality.

The role of snow is central because it produces connections among the sites. Thus, it is impossible to understand the actions and the strategic issues that actors and politicians face

511 regarding the re-launching of the $\mathrm{col} d u$ Coq resort, without looking at the other resorts in the

512 Chartreuse range. There are different attachments that are created between the particular areas 513 and sites (and thus between the actors). For example, the elected officials from Saint-Pierre 514 de Chartreuse do not want to develop the col du Coq for alpine skiing not because they no 515 longer believe in winter tourism but because they have other ambitions, such as re516 appropriating another small resort that is more accessible for them. The stagnation of the re517 launching of the col du Coq is above all the result of a political choice. When tourism policy 518 was redefined and a choice had to be made among the three micro-resorts of the PPR, the 519 resorts of Saint-Hilaire and Saint-Bernard were preferred to the detriment of col du Coq, 520 despite the opinion of the tourism service providers. This choice is explained in particular by 521 a disagreement among the mayors of the various municipalities and by the difficulty to set up 522 a tourism policy at the inter-municipality level. In short, the case of the col $d u$ Coq can only 523 be understood if the core of the problem is shifted towards the other tourism sites in 524 Chartreuse and if we retrace all the network connections.

525 Finally, the place given to snow in the network is different for each group of actors. 526 For some of them, snow does not have to define the 'collective' and an alternative form of 527 tourism has to be invented (this is the case, for example, of the ecologists, or some technicians 528 of protected areas). For others, snow should totally define the 'collective' and there can be no tourism unless it is winter tourism. But there again, the actors disagree. Some consider that 531 produce 'artificial' snow at a lower altitude: for example, at the Saint-Hilaire and Saint532 Bernard sites.

4.4. Reconfiguration of the accommodations and changes in tourist demand

Among the various changes that affect lower-altitude resorts, the transformation of tourist accommodation supply and the evolution of tourism demand are two phenomena that are closely linked and that are particularly de-structuring for mountain territories. The col du Coq does not rely on on-site tourist accommodations. However, these transformations are often at the heart of the debate between the proponents of greater development for the col $d u$ Coq and 
541 the defenders of alternative tourism. In fact, the evolution of tourists' tastes and the re-

542 structuring of the local accommodation supply are elements that are taken into account by the 543 actors. In contrast, the potential solutions to address these changes differ from one actor to 544 another.

The PPR territory has a relatively important tourism past thanks to the role played by its two winter sports resorts and the development of hang-gliding and paragliding since the 1980s. However, the distribution of tourist beds has been geographically unequal. The municipality of Saint-Pancrasse, which is nearer to the col du Coq, has never had tourist accommodations, even at the time when the old resort was working: "there are a few holiday cottages, there isn't much. Saint-Pancrasse is really a very small village" [elected representative of Saint-Pancrasse]. In contrast, the municipalities of Saint-Hilaire and SaintBernard have tourist accommodations that are mainly composed of holiday cottages. The golden age of lower-altitude winter tourism seems now a bygone era and the actors unanimously accept that there has been a great reduction in the number of beds available for tourists over the past few years: "there is a lot of real estate pressure on the PPR and in the majority of the rural cottages which had been bought some 30 years ago, people have realized their capital or have retired, and thus have sold the rural cottage which has become someone's main place of residence and no longer offers tourist accommodation" [elected representative Saint-Hilaire]. In 15 years, the number of beds available for tourists in the three municipalities dropped from 900 to about 500. The municipalities try to contain this crisis by finding solutions: "we try to keep the cottages we have, especially the communal cottages. We keep them, we try to help people who want to invest in cottages as much as possible, but knowing that our new clientele are customers from Grésivaudan [a valley situated below the PPR], therefore daily, weekend and holiday visitors" [elected representative from SaintBernard]. This is in fact a fundamental transformation that is taking place because the main problem is the shift from winter tourists (who are profitable) to excursionists for outdoor recreational activities (that are not profitable). Also, the difficult adaptation of the actors faced with the evolution of tourists' tastes is revealed in a tourist accommodation crisis, which has not kept up with demand and trends: "I've made some accommodation units in my house, which at one time corresponded to demand. Now it's more difficult because now [tourists] prefer an individual chalet, with every comfort inside, everything new, and so as to my units at home, I have great difficulty in renting them" [holiday cottage renter]. Some socio-cultural

573 changes reveal an individualization of tourist practices and tourists' search for independence,

574 which are out of sync with the current type of accommodation offered. This is not just with 
575 reference to the PPR as the center of the Chartreuse is also affected, even if its accommodation supply is focused on hotels: "With respect to Saint-Pierre de Chartreuse, $[\ldots]$ a tourist accommodation inventory has recently been conducted $[\ldots]$ and now we have 150 beds at most in the hotels. So, it's terrible. Now there are four or five establishments left when fifteen years ago there were eleven of us. It's dreadful" [elected representative of SaintPierre de Chartreuse]. The different resorts in the Chartreuse are therefore confronted with an accommodations restructuring which is taking two forms: on the one hand, a real-estate explosion that is favoring primary (and secondary) places of residence to the detriment of tourist accommodations; on the other hand, an aging supply of accommodation facilities (i.e. cottages on the PPR territory and hotels in Saint-Pierre de Chartreuse) that is not responding to the needs of an evolving clientele.

However, these difficulties are also related to another factor: the shortening of the winter season and the random snowfalls that mean that winter sports activities cannot be guaranteed anymore. As one of the actors explains: "If we want owners to rent accommodations for tourists, they must be able to rent both in winter and summer, otherwise, if they can only rent in the summer, they would rather rent the cottage for the whole year because there is a large demand for yearly rents, it's much simpler and more profitable" [association of friends of the col $d u$ Coq resort]. The tendency that has been observed is therefore a restructuring of tourist accommodation, which is itself not only a change but also the consequence of other changes.

4.5. The issue of tourism promotion

The issue of promoting tourism goes back to the way in which the 'captation' of sports and tourist publics is organized (Cochoy, 2007). It is therefore necessary to understand the connections among the actors involved in the promotion of the mountain range and to trace a network of inter-relations, which seems to be more about conflict than about cooperation. The organization of tourism promotion for the PPR is difficult. While the tourism office is responsible for implementing tourism policies, which are defined by the elected representatives, the exact opposite can be observed. The tourism office has completely redefined the rules by tinkering with the local legal context and redefining the terms of the tourism policy. By creating a sports and tourism event with an international scope (the Icarus

607 Cup, a paragliding event), it has legitimated at the local level its ability to define the events and/or developments necessary for promoting tourism on the PPR, and it has enrolled a 
multitude of organizations by granting them a share of the event revenues. Above all,

610 however, it has become financially independent from the public authorities thanks to this 611 event. The tourism office also controls the promotion of the mountain range at the territorial 612 level as it manages the Tourism Development Association (ADT). Thanks to this role, it has 613 managed to create attachments with the tourism suppliers in the PPR territory and to link the 614 different contexts of action in the Chartreuse region. But this hegemonic position generates 615 particularly conflictive relationships with the local elected representatives. The tourism office 616 thus partly controls the summer tourism activities (because of its grip on paragliding) but is 617 not able, however, to define the terms of the winter tourism policy. Its action is therefore 618 disputed by the elected representatives but remains an 'obligatory point of passage' (Callon, 619 1986) in the organization of territorial promotion.

620

\section{Conclusions}

622

The aim of this research has been to show how a tourist area can be transformed by various changes, especially climatic, and to provide a fine description of a tourist controversy by following the actors, their arguments, and organizational changes. What we call 'uncertain tourism' is a controversial situation that creates significant change around a tourism model and that leads to making political decisions. The case of climate change is rather specific because, as Latour (2017) suggested, there is scientific consensus on global warming being human-induced. Indeed, despite scientists' agreement, it remains difficult for locals to accept the idea of a changing climate that disrupts significantly a money-making tourism system in their region. The value of this study lies in showing from a case-study the concrete character of climate change, a phenomenon that typically remains abstract and hardly noticeable. Lowaltitude winter resorts presents an opportunity to observe organizational change and related conflicts, and ultimately, to question the territory government's capacity to take up the challenge, govern, and decide matters.

At an organizational level, the various situations described earlier question the actors' ability to adapt to change and to consider new solutions. The low-altitude winter sports resorts are experiencing deep changes because of their dependence on snowfall. For a long time, they were in a stable period from an organizational and operational point of view. The relationships were stable and there was a large number of 'intermediaries' (Latour, 2005). The

641 climatic risks and their effects have changed the situation and provoked the transition to a new phase, which is characterized by a transformation of the network. Relationships have to be 
643 renegotiated by the stakeholders and this has helped to redeploy a multitude of 'mediators'

644 (Latour, 2005). The situation is particularly unstable because snowfall uncertainty has led to 645 the deconstruction of the tourism network and to the reconfiguration of a new and different 646 one, on a larger scale. This uncertainty creates major conflicts between interdependent 647 stakeholders.

648 At a political level, the current climatic risks and snowfall problems have forced 649 elected officials to reconsider their resort management model. While for many years, climate 650 change (and its effects) has been a matter of fact, it has become a matter of concern (Latour, 651 2004) and winter tourism policy has had to be redefined. It then had to open the black box of 652 tourism policies in order to decide which sites are most likely to be profitable and apt at 653 having snow and attracting tourists, with environmentally friendly features. This new policy 654 did not provide full and immediate buy-in from the actors. It mainly generated a controversy, 655 which then reconfigured the relations and the organization of the resorts at the territorial level. 656 In the case under study, public actors have become more aware of the climatic changes and 657 their consequences on winter tourism than private actors, who continue to be convinced that 658 skiing can remain an attractive market for the territory.

659 While ANT has been of particular interest in tourism research over the last 10 years 660 (Van Der Duim, Ren, \& Johannesson, 2017; Beard, Scarles, \& Tribe, 2016), this article 661 contributes to the advancement of knowledge in this field for several reasons. First of all, 662 studies on tourist controversies are rare in the literature whereas the analysis of controversies 663 (or the mapping controversies) is at the center of the ANT approach. The instability of the 664 social is privileged in ANT and controversial situations, of which there are many in the field 665 of tourism, deserve special attention because they are often important organizational 666 transformations. In addition, the research contributes to the knowledge of networks in winter 667 sports resorts, as an extension of Paget et al.'s (2010) work. This research therefore had the 668 ambition to mobilize at the same time the traditional approach of ANT while mobilizing other 669 more recent theoretical evolutions. Thus, if the role of non-humans is particularly central in 670 the analysis of tourismscapes (Van Der Duim, 2007), as shown in the case of snow and the 671 deconstruction of the tourism network, the study also wished to integrate in the analysis of the 672 most recent elements around situations of uncertainty and controversy (Callon et al., 2011), 673 which presents an added value in the understanding of tourism policies. The case of climate 674 change is particularly relevant to these situations of political and organizational uncertainty 675 that Callon et al. (2011) describe, and the transfer in the field of tourist studies is particularly 676 interesting. Finally, the contribution of this research is mainly empirical since it contributes to 
a better knowledge, by the in-depth description of the controversy, of the transformation of a tourist area and the coordination difficulties of the actors to adapt to the changes.

The various changes discussed in this study question the resilience of actors responding to change but also their ability to resist change. While winter tourism has been a lucrative economic activity in France for many years, the actors have been suddenly faced with changes that challenge their mode of organizing and funding, and they have had to adapt to this new uncertainty. The political decision is particularly complex because it has to decide on the future of a site and of a tourism activity sector, by making decisions in a context of uncertainty (Callon et al., 2011), without being able to project on future snowfalls and the development of the winter sports market. Small French winter resorts persist only because of public subsidies despite repeated financial losses. In this case, however, there appears to be a political willingness to change the tourism model and to forsake a skiing product that is destined to disappear. The challenge resides in public and private actors' ability to imagine and develop alternative products that would attract tourists. This situation further highlights the divide in the French Alps between low-altitude resorts that suffer from climate change and the very profitable high-altitude stations that do not have to question their operations and business model. Climate change leads to widening economic and social inequalities in some tourism destinations. A managerial consequence may be to test new development models on low-altitude resorts that could help mitigate problematic changes in mid-altitude stations that are already and increasingly affected by this phenomenon. Ultimately, it is the sustainability of a tourism model that is questioned and tested by this study. Similar to seaside destinations, those small skiing resorts may become "disappearing destinations" (Gössling, Scott, Hall, Ceron, \& Dubois, 2012; Jones \& Phillips, 2011). At least mountain resorts can rethink and design their future: low-lying seaside destinations do not have that chance.

\section{Funding}

The Natural Regional Park of Chartreuse partially funded this research

\section{References}

Agrawala, S. (2007). Climate change in the European Alps. Adapting winter tourism and natural hazards management. Paris: OECD. 
Akrich, M., Callon, M., \& Latour, B. (2002). The key to success in innovation. International Journal of Innovation Management, 6, 187-225. DOI: 10.1142/S1363919602000550

Arnaboldi, M., \& Spiller, N. (2011). Actor-network theory and stakeholder collaboration: The case of cultural districts. Tourism Management, 32(3), 641-654. DOI: 10.1016/j.tourman.2010.05.016

Atout France (2009). Les chiffres clés du tourisme de montagne en France [The key statistics of mountain tourism in France] (7th ed.). Paris: Atout France.

Bardin, L. (2007). L'analyse de contenu [Content analysis]. Paris: Presses Universitaires de France.

Beard, L., Scarles, C., \& Tribe, J. (2016). Mess and method: Using ANT in tourism research. Annals of Tourism Research, 60, 97-110. DOI: 10.1016/j.annals.2016.06.005

Bloor, D. (1999). Anti-Latour. Studies in History and Philosophy of Science, 30(1), 81-112.

Callon, M. (1986). Some elements of a sociology of translation: Domestication of the scallops and the fishermen of Saint-Brieuc Bay. In: Law, J. (Ed.), Power, action and belief: A new sociology of knowledge? (pp. 196-233), London: Routledge.

Callon, M., Lascoumes, P., \& Barthe, Y. (2011). Acting in an uncertain world: An essay on technical democracy. Cambridge, MA: MIT Press.

Chateauraynaud, F. (1991). Forces et faiblesses de la nouvelle anthropologie des sciences [Strengths and weaknesses of the new anthropology of science]. Critique, 529-530, 459478.

Cochoy, F. (2007). A brief theory of the 'captation' of publics. Understanding the market with little red riding hood. Theory, Culture \& Society, 24(7-8), 203-223.

Cohen, E., \& Cohen, S. A. (2012). Current sociological theories and issues in tourism. Annals of Tourism Research, 39(4), 2177-2202. DOI: 10.1016/j.annals.2012.07.009

Decrop, A. (1999). Triangulation in qualitative tourism research. Tourism Management, 20(1), 157-161. DOI: 10.1016/S0261-5177(98)00102-2

Dedeke, A. (2017). Creating sustainable tourism ventures in protected areas: An actornetwork theory analysis. Tourism Management, 61, 161-172. http://dx.doi.org/10.1016/j.tourman.2017.02.006

Dubois, M. (2007). La construction métaphorique du collectif: dimensions implicites du prêtà-penser constructiviste et théorie de l'acteur-réseau [The metaphorical construction of the collective: Implicit dimensions of the constructivist ready-to-think and actornetwork theory]. L'Année sociologique, 57(1), 127-150. DOI: 10.3917/anso.071.0127

Dubois, G., \& Ceron, J.-P. (2006). Tourism and climate change: Proposals for a research 
agenda. Journal of Sustainable Tourism, 14(4), 399-415. DOI: 10.2167/jost539.0

Elsasser, H., \& Messerli, P. (2001). The vulnerability of the snow industry in the Swiss Alps. Mountain Research and Development, 21(4), 335-359. DOI: 10.1659/02764741(2001)021[0335:TVOTSI]2.0.CO;2

Elsasser, H. B., \& Bürki, R. (2002). Climate change as a threat to tourism in the Alps. Climate Research, 20(3), 253-257. DOI: 10.3354/cr020253

Franklin, A. (2004). Tourism as an ordering: Towards a new ontology of tourism. Tourist Studies, 4(3), 277-301. DOI: 10.1177/1468797604057328

Friedberg, E. (1996). Powers and rules. The organizational dynamics of collective action. Paris: Avebury.

Frochot, I., \& Kreziak, D. (2008). Customers' perceptions of ski resorts' images: Implications for resorts' positioning strategies. Tourism and Hospitality Research, 8(4), 298-308. DOI: $10.1057 /$ thr.2008.27

Garfinkel, H. (1967). Studies in ethnomethodology. Cambridge: Polity Press.

Glaser, B., \& Strauss, A. (1968). The discovery of grounded theory. London: Weidenfeld and Nicolson.

Gössling, S., Scott, D., Hall, C. M., Ceron, J. P., \& Dubois, G. (2012). Consumer behaviour and demand response of tourists to climate change. Annals of Tourism Research, 39(1), 36-58. DOI: 10.1016/j.annals.2011.11.002

Grossetti, M. (2007). Les limites de la symétrie [The limits of symmetry]. Sociologies [On line], retrieved from http://sociologies.revues.org/712

Guerin, J. P. (1984). L'aménagement de la montagne. Politiques, discours et productions d'espaces. Gap: Editions Ophrys.

Hollinshead, K. (2006). The shift to constructivism in social inquiry: Some pointers for tourism studies. Tourism Recreation Research, 31(2), 43-58. DOI: $10.1080 / 02508281.2006 .11081261$

Jamal, T., \& Hollinshead, K. (2001). Tourism and the forbidden zone: The underserved power of qualitative inquiry. Tourism Management, 22(1), 63-82. DOI: 10.1016/S02615177(00)00020-0

Johannesson, G. (2005). Tourism translations: Actor-network theory and tourism research. Tourist Studies, 5(2), 133-150. DOI: 10.1177/1468797605066924

Jones, A. L., \& Phillips, M. R. (Eds.) (2011). Disappearing destinations: Climate change and future challenges for coastal tourism. Wallingford: CABI. 
Jørgensen, M.-T. (2017). Reframing tourism distribution - Activity Theory and ActorNetwork

Theory.

Tourism

Management,

62 ,

312-321. https://doi.org/10.1016/j.tourman.2017.05.007

Koenig, U., \& Abegg, B. (1997). Impacts of climate change on winter tourism in the Swiss Alps. Journal of Sustainable Tourism, 5(1), 46-58. DOI: 10.1080/09669589708667275

782

783

Law, J. (1994). Organizing modernity. Oxford: Blackwell.

Latour, B. (1987). Science in action. How to follow scientists and engineers through society. Cambridge, MA: Harvard University.

Latour, B. (1993). We have never been modern. Brighton: Harvester Wheatsheaf.

Latour, B. (1996). Aramis or the love of technology. Cambridge, MA: Harvard University.

Latour, B. (2004). Politics of Nature: How to Bring the Sciences into Democracy. Cambridge, MA: Harvard University.

Latour, B. (2005). Reassembling the social. An introduction to actor-network-theory. Oxford: Oxford University Press.

Latour, B. (2017). Facing Gaia: Eight lectures on the new climatic regime. Cambridge: Polity Press.

Miles, M., \& Huberman, M. (1994). Qualitative data analysis: An expanded sourcebook (2nd ed.). Thousand Oaks, CA: Sage.

Moen, J., \& Fredman, P. (2007). Effects of climate change on alpine skiing in Sweden. Journal of Sustainable Tourism, 15(4), 418-437. DOI: 10.2167/jost624.0

Morrison, C., \& Pickering, C. (2012). Perceptions of climate change impacts, adaptation and limits to adaption in the Australian Alps: The ski-tourism industry and key stakeholders. Journal of Sustainable Tourism, 21(2), 1-19. DOI:10.1080/09669582.2012.681789

Mucchielli, A. (1996). Interview non directive (ou compréhensive) centrée [Centered nondirective interview]. In: Mucchielli, A. (Ed.), Dictionnaire des méthodes qualitatives en sciences humaines et sociales [Dictionary of qualitative methods in human and social sciences] (pp. 109-110), Paris: Armand Colin.

Paget, E., Dimanche, F., \& Mounet, J.-P. (2010). A tourism innovation case: An actornetwork approach. Annals of Tourism Research, 37(3), 828-847. DOI: 10.1016/j.annals.2010.02.004

Pernecky, T., \& Jamal, T. (2010). (Hermeneutic) Phenomenology in tourism studies. Annals of Tourism Research, 37(4), 1055-1075. DOI: 10.1016/j.annals.2012.07.009

Phillimore, J., \& Goodson, L. (2004). Qualitative research in tourism: Ontologies, epistemologies and methodologies. London: Routledge. 
Rech, Y., \& Paget, E. (2017). Saisir les transformations des sports de nature par la théorie de l'acteur-réseau [Using actor network theory to understand the transformation of nature sports]. Sciences de la société, 101.

Ren, C., Pritchard, A., \& Morgan, N. (2010). Constructing tourism research: A critical inquiry. Annals of Tourism Research, 37(4), 885-904. DOI: 10.1016/j.annals.2009.11.00

Ren, C. (2011). Non-human agency, radical ontology and tourism realities. Annals of Tourism Research, 38(3), 858-881. DOI: 10.1016/j.annals.2010.12.007

Riley, W. R., \& Love, L. L. (2000). The state of qualitative tourism research. Annals of Tourism Research, 27(1), 164-187. DOI: 10.1016/S0160-7383(99)00068-

Rodger, K., Moore, S., \& Newsome, D. (2009). Wildlife tourism, science and actor network theory. Annals of Tourism Research, 36(4), 645-666. DOI: 10.1016/j.annals.2009.06.001

Scott, D., McBoyle, G., Minogue, A., \& Mills, B. (2006). Climate change and the sustainability of ski-based tourism in Eastern North America: A reassessment. Journal of Sustainable Tourism, 14(4), 376-398. DOI: 10.2167/jost550.0

Simpson, M. C., Gössling, S., Scott, D., Hall, C.M., \& Gladin, E. (2008). Climate change adaptation and mitigation in the tourism sector: Frameworks, tools and practices. Paris: UNEP, University of Oxford, UNWTO, WMO.

Soboll, A., \& Dingeldey, A. (2012). The future impact of climate change on Alpine winter tourism: A high-resolution simulations system in the German and Austrian Alps. Journal of Sustainable Tourism, 20(1), 101-120. DOI: 10.1080/09669582.2011.610895 STRMTG (2015). Rapport d'activité 2015 [Activity report 2015]. Saint-Martin d'Hères (France): Service Technique des Remontées Mécaniques et des transports guidés (STRMTG), Ministère de l'Ecologie, du Développement Durable et de l'Energie. Retrieved from http://www.strmtg.equipement.gouv.fr/IMG/pdf/rapport-activiteSTRMTG-2015.pdf

Thietart, R.-A. (2001). Doing management research: A comprehensive guide. London: Sage.

Tribe, J. (2010). Tribes, territories and networks in the tourism academy. Annals of Tourism Research, 37(1), 7-33. DOI: 10.1016/j.annals.2009.05.001

Urry, J. (2005). Sociologie des mobilités [Sociology of mobilities]. Paris: Armand Colin.

Vanat, L. (2018). International report on snow and mountain tourism: Overview of the key industry figures for ski resorts. Geneva (Switzerland): Laurent Vanat. Retrieved from http://www.vanat.ch/RM-world-report-2018.pdf

Van Der Duim, R. (2005). Tourismscapes: An actor-network perspective on sustainable 
tourism development. Doctoral dissertation, Dissertation Wageningen University, The $846 \quad$ Netherlands.

847 Van Der Duim, R. (2007). Tourismscapes: An actor-network perspective. Annals of Tourism Research, 34(4), 961-976. DOI: 10.1016/j.annals.2007.05.008

Van Der Duim, R., Ren, C., \& Johannesson, G. (2017). ANT: A decade of interfering with tourism. Annals of Tourism Research, 64, 139-149. DOI: 10.1016/j.annals.2017.03.006

851 Walle, A. H. (1997). Quantitative versus qualitative tourism research. Annals of Tourism Research, 24(3), 524-536. DOI: 10.1016/S0160-7383(96)00055-2

853 Weber, M. (1978). Economy and society. Berkeley, CA: University of California.

854 Westwood, S., Morgan, N., \& Pritchard, A. (2006). Situation, participation and reflexivity in tourism research: Furthering interpretive approaches to tourism enquiry. Tourism Recreation Research, 31(2), 33-42.

857 Wolfsegger, C., Gössling, S., \& Scott, D. (2008). Climate change risk appraisal in the 858 Austrian ski industry. Tourism Review International, 12(1), 13-23. DOI: $10.3727 / 154427208785899948$

860 Yin, R. (2003). Case study research: Design and methods (3rd ed.). Thousand Oaks, CA: 861 Sage. 
Figure 1: Map of the site investigated

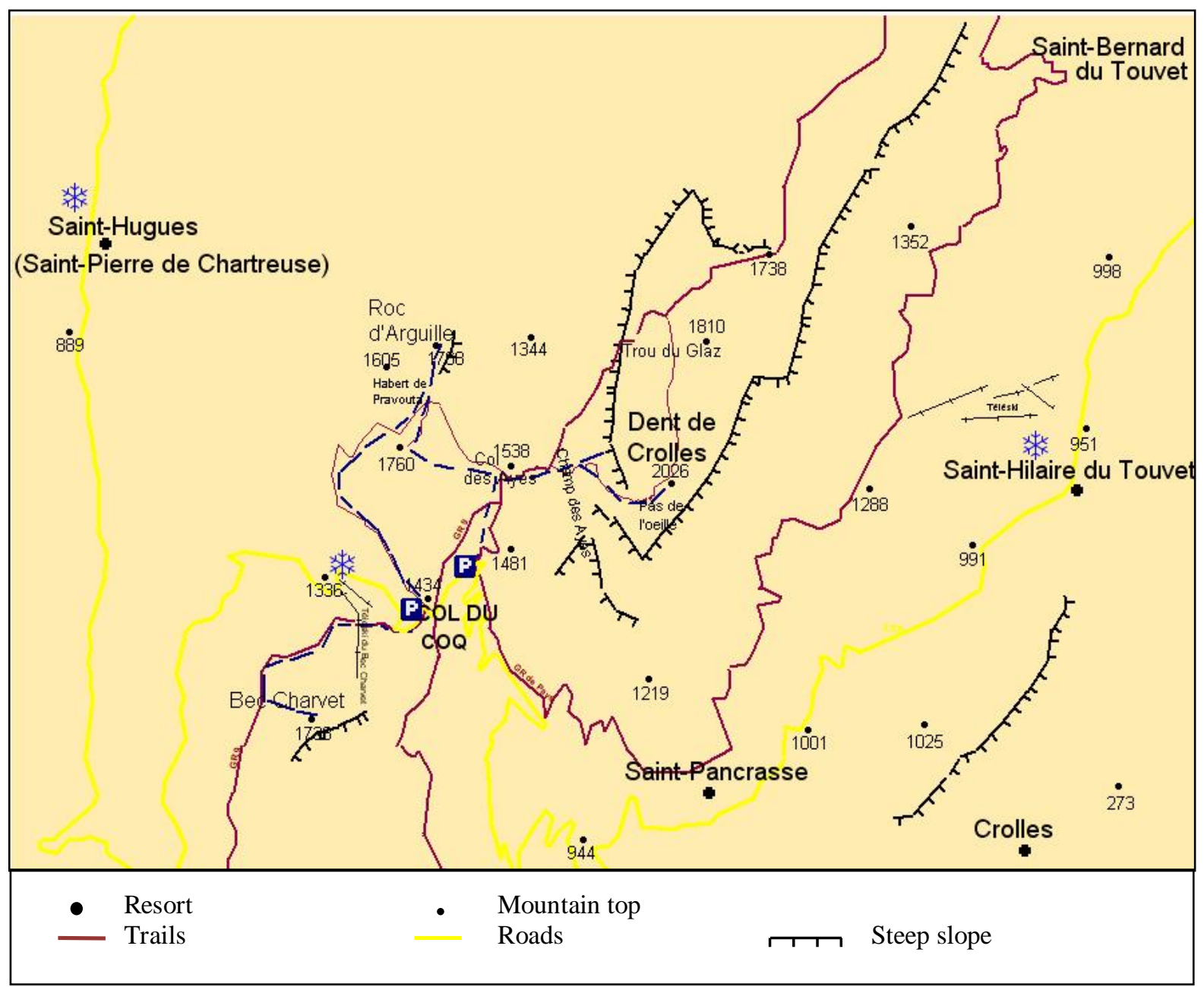


Table 1: Type and number of interviewed actors

\begin{tabular}{|c|c|c|}
\hline Number of interviews & Type of structure & Job titles or activities \\
\hline \multicolumn{3}{|l|}{$\begin{array}{l}\text { Protected area and/or } \\
\text { environmental managers }(n=6)\end{array}$} \\
\hline & $\begin{array}{l}\text { Natural Regional Park of } \\
\text { Chartreuse }\end{array}$ & Scientific manager \\
\hline & $\begin{array}{c}\text { Natural Regional Park of } \\
\text { Chartreuse }\end{array}$ & $\begin{array}{l}\text { Manager of outdoor } \\
\text { recreation }\end{array}$ \\
\hline & Departmental council & Environmental manager \\
\hline & Departmental council & Environmental Guide \\
\hline & $\begin{array}{l}\text { Nature Reserve of } \\
\text { Chartreuse }\end{array}$ & Guard \\
\hline & National Forestry Office & Technicians \\
\hline \multicolumn{3}{|l|}{$\begin{array}{l}\text { Municipal and inter-municipal } \\
\text { elected officials }(n=5)\end{array}$} \\
\hline & Saint-Hilaire city & Elected representative \\
\hline & $\begin{array}{l}\text { Saint-Pierre de Chartreuse } \\
\text { city }\end{array}$ & Elected representative \\
\hline & $\begin{array}{l}\text { Saint-Bernard city / PPR } \\
\text { community }\end{array}$ & Elected representative \\
\hline & Saint-Pancrasse city & Elected representative \\
\hline & Local council community & Elected representative \\
\hline \multicolumn{3}{|l|}{ Tourist offices $(n=2)$} \\
\hline & $\begin{array}{c}\text { Tourism office (Saint- } \\
\text { Pierre de Chartreuse city) }\end{array}$ & Director \\
\hline & $\begin{array}{c}\text { Tourism office (Saint- } \\
\text { Hilaire city) }\end{array}$ & Director \\
\hline \multicolumn{3}{|l|}{ Host $(n=1)$} \\
\hline & Holiday cottage renter & Director \\
\hline \multicolumn{3}{|l|}{$\begin{array}{l}\text { Recreational activity providers } \\
(n=5)\end{array}$} \\
\hline & Guides company & $\begin{array}{l}\text { Mountain guide and ski } \\
\text { instructor }\end{array}$ \\
\hline & Hiking provider & Independent and journalism \\
\hline & Hiking office guides & Director \\
\hline & Paragliding schools & Director \\
\hline & Paragliding provider & Independent \\
\hline \multicolumn{3}{|l|}{$\begin{array}{l}\text { Sports and recreation } \\
\text { associations }(n=3)\end{array}$} \\
\hline & Climbing association & President \\
\hline & $\begin{array}{l}\text { Icare cup Events and } \\
\text { association of friends of the } \\
\text { col } d u \operatorname{Coq} \text { resort }\end{array}$ & President \\
\hline & Hunting association & President \\
\hline \multicolumn{3}{|l|}{$\begin{array}{l}\text { Environmental protection NGO } \\
(n=1)\end{array}$} \\
\hline & Mountain Wilderness & Project manager \\
\hline
\end{tabular}




\begin{tabular}{|l|c|c|}
\hline Other $\mathbf{( n = 2 )}$ & & Departmental council \\
\hline & & $\begin{array}{c}\text { Director of the tourism } \\
\text { department }\end{array}$ \\
\hline & Farmer \\
\hline
\end{tabular}




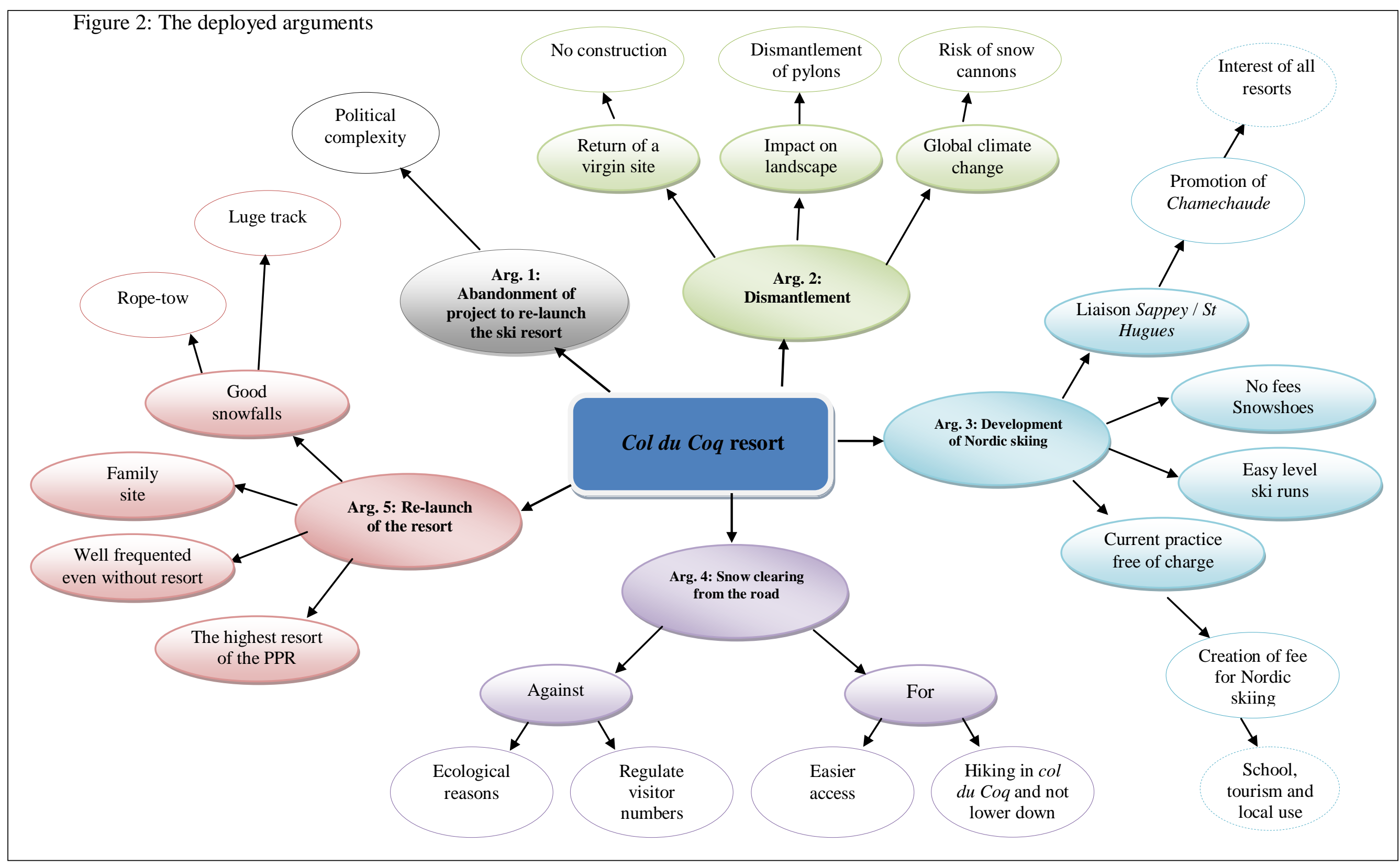

